\title{
Między tradycją i modernizmem. Architektura szkół lubelskich okresu międzywojnia
}

\section{Elżbieta Błotnicka-Mazur}

e-mail: elamazur@kul.pl

Instytut Historii Sztuki, Katolicki Uniwersytet Lubelski Jana Pawła II

\begin{abstract}
Streszczenie: $W$ artykule zostały przedstawione projekty wybranych szkół, powstałe w Lublinie w okresie międzywojennym Przeanalizowano ich formę, zmieniającą się wraz z przemianami trendów stylistycznych, popularnych w tym czasie w architekturze polskiej, począwszy od tradycjonalizmu, popularnego w pierwszej połowie lat 20., przez stopniowe upraszczanie formy i detalu końca lat 20., po obiekty reprezentujące dojrzały modernizm od połowy lat 30. XX wieku.
\end{abstract}

Słowa kluczowe: architektura szkół, dwudziestolecie międzywojenne, tradycjonalizm, modernizm

\section{Wprowadzenie}

W 1918 roku poziom szkolnictwa podstawowego w Polsce był bardzo niski, zwłaszcza na terenach byłego zaboru rosyjskiego, w ramach którego znajdowała się przeważająca część Lubelszczyzny. Pierwszy akt prawny II RP dotyczący oświaty, uchwalony w lutym 1919 roku, wprowadzał powszechny obowiązek szkolny i pozostawał w mocy do 1939 roku. Dotychczasowe szkoły elementarne przemianowano na powszechne, w których nauka - zgodnie z dekretem bezpłatna - miała odbywać się przez 7 lat dla uczniów między 7 i 14 rokiem życia [Przesmycka, Miłkowska 2011: 168] ${ }^{1}$.

Sytuacja lokalowa szkolnictwa powszechnego w Lublinie tuż po odzyskaniu niepodległości była wyjątkowo trudna. Okupanci pozostawili miastu niewielką ilość budynków szkolnych, a liczba dzieci przekraczająca wówczas 4100 stale rosła: przykładowo w latach 1921/22 - było to 7656 , a w roku szkolnym 1925/26 już 9057 osób ${ }^{2}$. Sytuacja zmusiła Zarząd Miejski do zaciągania kredytów, które rozwiązywały problem na bieżąco - wynajem lokali w prywatnych domach na cele szkolne - oraz dawały nadzieję na budowę nowych obiektów w latach 1923-1925 wybudowano dwie drewniane szkoły: przy ul. Długosza na Wieniawie oraz przy ul. Długiej na Kośminku i jedną murowaną przy ul. Św. Mikołaja na Czwartku. W drugiej połowie lat 20. XX wieku szkolny ruch budowlany został zahamowany na skutek innych dużych inwestycji miejskich (wodociągi i kanalizacja), a co za tym idzie obciążeniem miasta spłatą pożyczki tzw. ulenowskiej. Po kilkuletniej stagnacji wywołanej także ogólnoświatowym kryzysem gospodarczym Zarząd Miejski podjął konkretne działania zmierzające do budowy nowych szkół w oparciu o kredyty, która w dłuższej perspektywie była znacznie bardziej opłacalna dla miasta, niż kosztowne wypełnianie "skarbonek" prywatnych właścicieli lokali.

Podział miasta przez Kuratorium Okręgu Szkolnego Lubelskiego na 12 obwodów szkolnych miał usprawnić proporcjonalne przyporządkowanie wzrastającej liczby uczniów do poszczególnych placówek, a przede

1 Por. także: Monografia m. Lublina za czas od 1917 do 1927 roku, red. T. Dobrowolski, Lublin 1928, s. 28, nota bene z interesującą okładką ozdobioną drzeworytem Kazimierza Wiszniewskiego i drzeworytami Kazimierza Pieniążka w tekście, wydana z okazji 10-lecia odzyskania przez Polskę niepodległości.

2 Archiwum Państwowe w Lublinie [dalej: APL], Akta miasta Lublina [dalej: AmL ] 1918-1939, Sprawy budowy nowych szkót 1935 r., k. 12 , $15-16$, sygn. 3724 
wszystkim ułatwić wytypowanie najlepszych lokalizacji dla nowych gmachów. W 1939 roku na 30 istniejących szkół powszechnych 10 obiektów (w tym sześć drewnianych i cztery murowane), mieszczących 17 szkół, należało do miasta. Osiem z nich wybudowano od podstaw, jeden przebudowano (przy ul. Bronowickiej na zrębie dawnej rzeźni), a budynek przy ul. Lipowej 5 ukończono już w czasie wojny. Z przyczyn ekonomicznych częstą praktyką było projektowanie i realizacja szkół tzw. „bliźniaczych”, w których pod jednym - dosłownie - dachem lokowano po dwie placówki. W odróżnieniu od szkół w mniejszych miejscowościach województwa lubelskiego (chociaż w praktyce problem dotyczył całego kraju), w których początkowo funkcjonowały niemal wyłącznie placówki jedno i dwuklasowe, w Lublinie nauka odbywała się w szkołach najwyżej zorganizowanych, czyli siedmioklasowych ${ }^{3}$.

W lepszej sytuacji były szkoły średniego szczebla, z uwagi na to, iż większość z nich pozostawała w rękach prywatnych. W okresie międzywojennym w Lublinie działało 17 szkół średnich ogólnokształcących i 6 zawodowych. Cztery z nich zdołały w tym okresie wybudować własne gmachy: Gimnazjum im. Stanisława Staszica (upaństwowione w 1919 roku), Męskie Prywatne Gimnazjum Biskupie, Szkoła Przemysłowo-Handlowa Żeńska (upaństwowiona w 1920 roku) i Średnia Szkoła Budownictwa. Nie został zrealizowany Projekt Prywatnego Gimnazjum Elektrycznego i Mechanicznego [Janeczek 2004].

Formę architektoniczną gmachów szkolnych Lublina, zaprojektowanych w okresie międzywojennym, można uznać za swoisty "papierek lakmusowy” nurtów i tendencji charakterystycznych w określonych przedziałach czasowych dla architektury miasta w ogóle. Przedmiotem zainteresowania będą wyłącznie obiekty murowane - drewniane placówki: budynek szkół powszechnych nr 15 i 16 przy ul. Długiej, projektowany przez lgnacego Kędzierskiego w 1922 roku, szkoła powszechna nr 18 przy ul. Długosza zaprojektowana ok. 1923 roku oraz siedziba szkół nr 4 i 20 przy zbiegu ulic Lubartowskiej i Obywatelskiej, autorstwa Leona Banaszewskiego z 1937, zostały zniszczone lub rozebrane. Analizowane obiekty zostały pogrupowane według kryteriów formalnych, najczęściej pokrywających się z chronologicznymi. Stąd w jednym podrozdziale znajdą się szkoły zarówno powszechne - podstawowe, jak i średniego szczebla.

\section{Nurt tradycjonalistyczny - przewaga form historycznych}

Budynek publicznych Szkół Powszechnych nr 3 i 6 na Czwartku przy ul. Św. Mikołaja 10 (obecnie IV LO, ul. Szkolna 4) reprezentuje swoją formą nurt narodowy. Zaprojektowany w 1921 roku przez Ignacego Kędzierskiego gmach został założony na nieregularnym rzucie, przypominającym literę T, z czterokondygnacyjną główną częścią i dwukondygnacyjną salą gimnastyczną ${ }^{4}$. W budowli zwraca uwagę mansardowy dach z trzema facjatami. Natomiast trójkątny szczyt o nieregularnej linii, którego wklęsłe łuki przypominają spływy wolutowe, oraz pasy lizen przywołują echa architektury barokowej. Charakterystyczne dla projektów Kędzierskiego z tego okresu jest akcentowanie kondygnacji parteru poprzez stosowanie okien o półkolistym wykroju - powtórzonym przez okrągłe okno nad wejściem głównym na osi fasady na parterze - w odróżnieniu od okien prostokątnych, wielopolowych na wyższych kondygnacjach.

W kontekście obiektów o tradycyjnych detalach, które w ostatecznym rozrachunku całego dwudziestolecia międzywojennego pozostają w mniejszości w stosunku do wybudowanych szkół o formach modernistycznych, warto wspomnieć o trzech innych projektach I. Kędzierskiego, powstających kolejno dla budynku szkół nr 8 i 13 przy ul. Lipowej (il. 1).

3 Problem architektury szkół wiejskich na Lubelszczyźnie podejmuje cytowany artykuł [Przesmycka, Miłkowska 2011] oraz [Przesmycka, Rzączyńska 2008]

4 Niewykończony obiekt oddano do użytku pod koniec 1924 roku. APL Inspekcja Budowlana [dalej:IB], Akta nieruchomości położonej przy ul. Św. Mikołaja 10 w Lublinie, sygn. 5364. 




Ryc. 1. Niezrealizowany projekt szkoły powszechnej przy ul. Lipowej, proj. I. Kędzierski 1922, widoki od frontu: I wersja (u góry), II wersja (pośrodku), za: APL AmL, sygn. 1831, III wersja (u dołu), za: APL IB, sygn. 2507, kopie projektów za zgodą Archiwum Państwowego w Lublinie

Ostatecznie żaden z nich nie doczekał się realizacji. Pierwszy z nich, z 1922 roku, przeznaczony dla jednej tylko 7-klasowej szkoły powszechnej, ukazuje jednopiętrowy budynek o wysokim spadzistym dachu, przypominający formą dwory lub pałace doby nowożytnej ${ }^{5}$. Dekoracja architektoniczna skupia się w obrębie ryzalitu na osi budowli z zamkniętym półkoliście wejściem głównym, flankowanym pilastrami. Zdobienia wieńczącego ryzalit naczółka w postaci spływów wolutowych i owalnie wykrojonego okna można odnaleźć w późnobarokowej architekturze rezydencjonalnej i sakralnej. Wykonany wkrótce potem przez tego samego architekta, na życzenie lubelskich władz oświatowych, następny projekt - tym razem dla dwóch placówek - formalnie również był silnie osadzony w tradycji. Znacznie większy, dwupiętrowy gmach z użytkowym poddaszem w mansardowym dachu z szeregiem lukarn, miał być założony na planie zbliżonym do litery E. Podobne detale, występujące w pierwszym projekcie w centralnie umieszczonym ryzalicie, tu projektant umieścił na skrajach głównego korpusu gmachu, gdzie znalazły się analogiczne ryzality z odrębnymi wejściami do każdej ze szkół, o bardziej jednak uproszczonych formach. Mimo wprowadzonych zmian ta propozycja nie uzyskała akceptacji i została opatrzona długą listą zarzutów: że zbyt kosztowny w budowie - ze względu na mansardowy dach - a przy tym zanadto dekoracyjny, o niezbyt dobrym rozplanowaniu wnętrza i niekorzystnie sytuujący budynek względem światła ${ }^{6}$. Za trzecim razem Kędzierski zaproponował jednak jeszcze okazalszą budowlę. Zamienił wprawdzie mansardowy dach z lukarnami na wysoki, prosty, czterospadowy, ale trudno tu dostrzec zasadnicze uproszczenie detalu. Natomiast wprowadzone zmiany niewątpliwie korzystnie wpłynęły na proporcje całej budowli. Było to: przesunięcie głównych wejść bliżej osi, rezygnacja z ryzalitów na rzecz kolumnowych portyków w wielkim

5 APL IB, Akta nieruchomości położonej przy ul. Lipowej 5, sygn. 2507; APL AmL, Budowa szkoty powszechnej przy ul. Lipowej 1922-1933, sygn. 1831. Z przyczyn ekonomicznych - przewidywane oszczędności plus braki odpowiednio zlokalizowanych działek pod budowę nowych placówek - nie wzięto jego realizacji pod uwagę, a Kędzierskiego zobligowano do wykonania nowego projektu.

6 APL AmL Budowa szkoły powszechnej przy ul. Lipowej 1922-1933, sygn. 1831, Pismo Ministerstwa Wyznań Religijnych i Oświecenia Publicznego w Warszawie z dnia 18 grudnia 1922 roku nr 25514/I. 
porządku, czy korekta formy trójkątnych zwieńczeń. Gdyby projekt został zrealizowany, mógłby być jedną z ciekawszych budowli nawiązujących swoją szatą architektoniczną do modnego w tym czasie stylu dworkowego.

Warto odnotować, że tradycjonalizm inspirowany formami budownictwa ludowego był praktycznie w większych miastach nieobecny - także w Lublinie. Natomiast architekci chętnie korzystali z takich wzorców projektując powszechne szkoły wiejskie, do czego zachęcały ich opracowania o charakterze metodycznym [Holewiński 1921: $25-26]^{7}$.

\section{Zmodernizowany historyzm}

W drugiej połowie lat 20. XX wieku w projektach szkół można zaobserwować stopniową rezygnację z historyzującego detalu i coraz większe wpływy modernizmu, widoczne np. w prostych otworach okiennych, pozbawionych dekoracyjnej oprawy, czy zamianie wywodzących się z klasycyzmu pilastrów na "bezporządkowe” lizeny. Wciąż dominują symetryczne rozwiązania fasad i akcentowanie części elewacji z głównym wejściem ${ }^{8}$ Do tej grupy można włączyć kilka lubelskich realizacji.

Monumentalną formę otrzymał gmach prywatnego Męskiego Gimnazjum Biskupiego przy ul. Krzywej na Czwartku (ob. XXI LO i Gimnazjum im. Św. Stanisława Kostki, tzw. Biskupiak przy ul. ks. Michała Słowikowskiego), autorstwa Jerzego Siennickiego (proj. 1927, budowa trwała do 1934 roku). Pierwotna koncepcja budowli na rzucie wielokąta, z wewnętrznym dziedzińcem nie została zrealizowana i ostatecznie plan gmachu przypomina literę $V$ ze ściętym narożnikiem (il. 2). O wyrazie architektonicznym obiektu decyduje forma głównego korpusu na wysokim cokole, obejmującym sutereny i parter oraz czterospadowy dach z szeregiem lukarn. Ryzalit na ściętym narożu z wejściem głównym cechuje już pewna prostota wertykalnych podziałów osi gładkimi pilastrami, kanelowanymi w dolnej kondygnacji "cokołu” (il. 3).

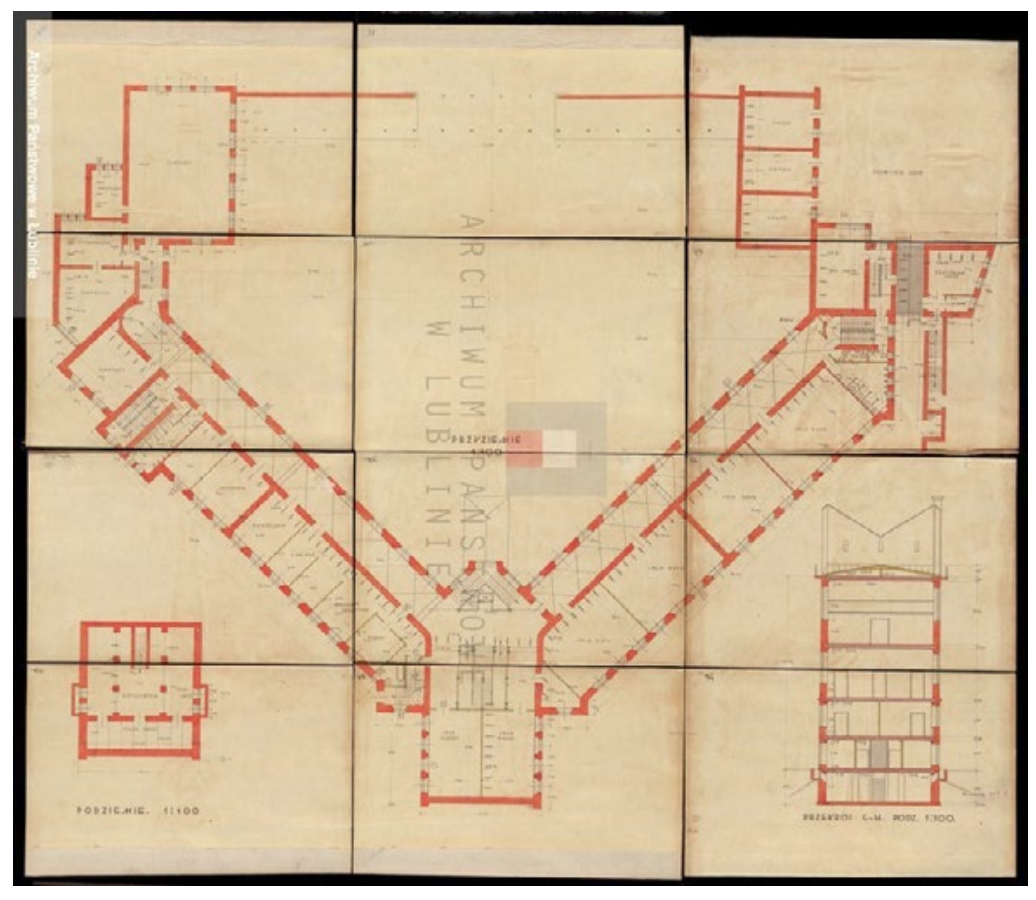

Ryc. 2. Męskie Gimnazjum Biskupie, proj. Jerzy Siennicki 1927, rzut parteru, za: APL UWL-V-WKB, sygn. 1486, kopia projektu za zgodą Archiwum Państwowego w Lublinie

7 To dość szczegółowe opracowanie, będące poszerzoną wersją publikacji z 1908 roku [Holewiński 1908], zawierało wskazówki dotyczące funkcjonalnych rozwiązań budynku szkolnego, jego wyposażenia i kwestii higieny. Por.: [Pszczółkowski 2015: 98].

8 Więcej o klasyfikacji form „przejściowych” zob. [Pszczółkowski 2014: 145-165]. 


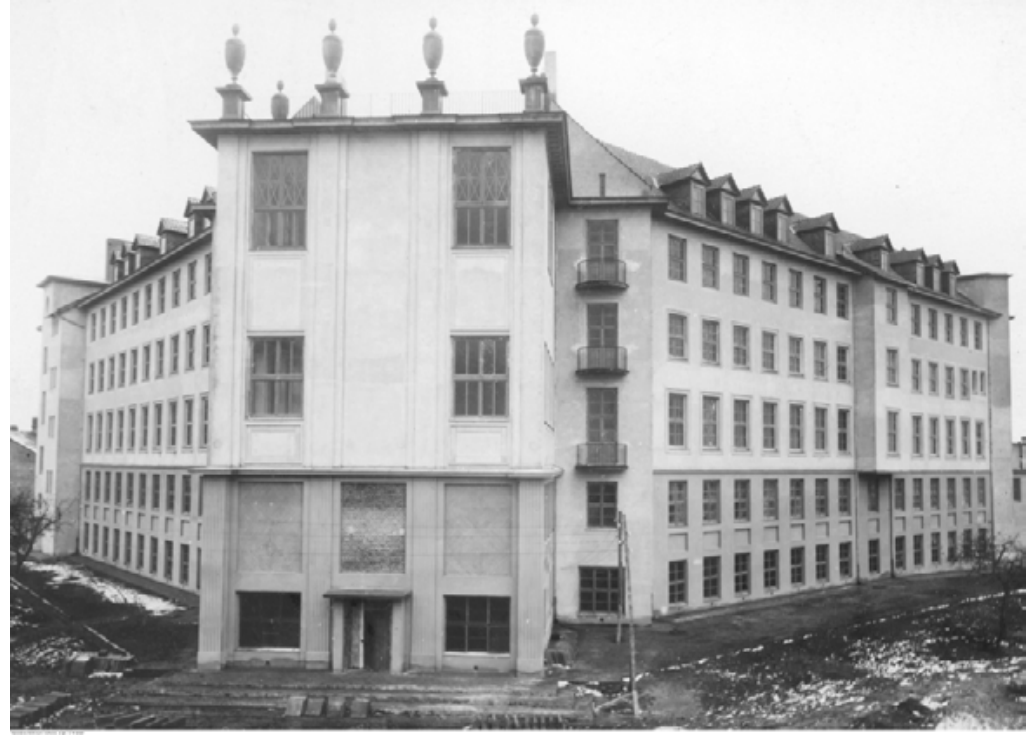

Ryc. 3. Męskie Gimnazjum Biskupie, proj. Jerzy Siennicki 1927, fot. ok. 1934, zbiory Narodowego Archiwum Cyfrowego, sygn. PIC_1-N-2018

Kolejna budowla w tej grupie, gmach szkoły Przemysłowo-Handlowej Żeńskiej przy ul. Spokojnej (ob. Zespół Szkół Odzieżowo-Włókienniczych i Zespół Szkół Gastronomicznych) to dzieło przywoływanego już kilkakrotnie Ignacego Kędzierskiego, z 1928 roku. Asymetrii rzutu zbliżonego do odwróconej litery „L" towarzyszy dość swobodne zestawienie bryły głównego korpusu z kilkoma ryzalitami, tworzące kompozycję przestrzenną o zróżnicowanych wysokościach (il. 4). W zakresie detalu budowla tkwi jeszcze w stylistyce minionych epok: trójkątny naczółek ryzalitu z wejściem głównym i boniowane narożniki wyraźnie zaznaczonego cokołu dolnej kondygnacji. Nota bene podobnie zwieńczony ryzalit zastosował w projekcie swojej lubelskiej willi przy ul. Grottgera 8, pochodzącej dokładnie z tego samego okresu, Bohdan Kelles-Krauze, zaprzyjaźniony z Kędzierskim lubelski architekt powiatowy. Wykorzystana przez Kędzierskiego uskokowa forma lizen daje jednak bardziej interesujące efekty światłocieniowe, niż gładkie pasy muru w domu własnym drugiego architekta [por:: Błotnicka-Mazur 2011: 324-327].

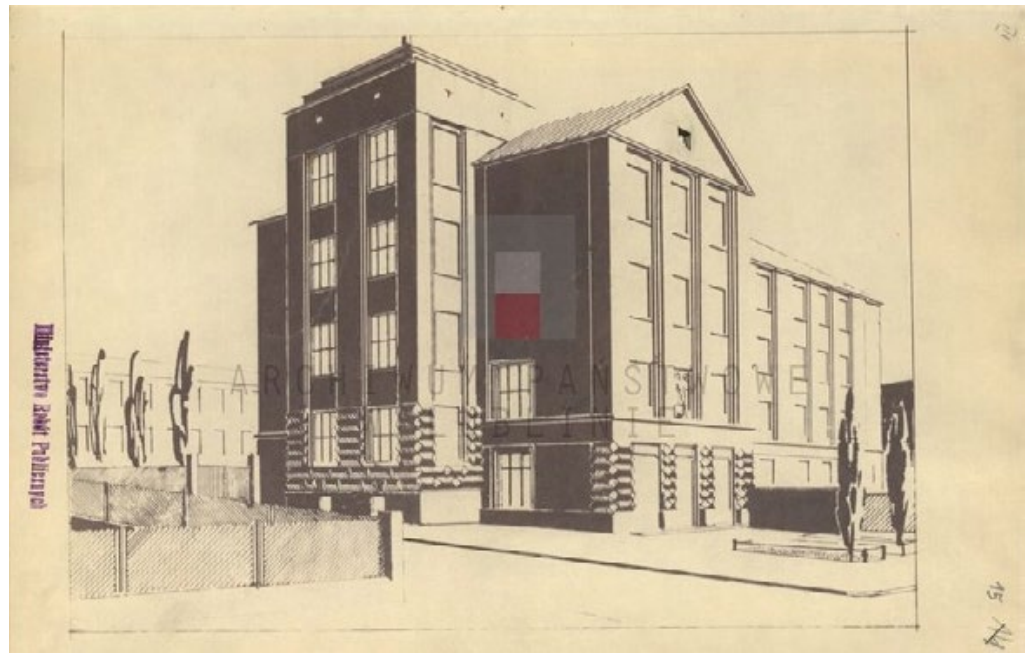

Ryc. 4. Szkoła Przemysłowo-Handlowo Żeńska, proj. I. Kędzierski 1928, aksonometria, za: APL UWL-V-WKB, sygn. 1490, kopia projektu za zgodą Archiwum Państwowego w Lublinie 
Boniowanie narożników i kondygnacji cokołu można odnaleźć w budynku Gimnazjum im. Stanisława Staszica przy Alejach Racławickich (ob. I LO im. Staszica). Projekt gmachu wykonał warszawski architekt Ludwik Szymański w 1930 lub 1931 roku $^{10}$. Prostota ogólnego wyrazu budowli założonej na rzucie litery U została osiągnięta poprzez niewielkie zróżnicowanie wysokości jej poszczególnych członów - frontowych ryzalitów na skrajach elewacji, głównego korpusu i ryzalitu na osi tylnej elewacji - i nakrycie ich stosunkowo płaskimi, czterospadowymi dachami. Uwagę zwracają zdwojone pilastry flankujące wejście z podłużnymi pasami okienek pomiędzy nimi. Dekoracja pozostałych elewacji, podobnie, jak w przypadku poprzedniego obiektu, jest dosyć uproszczona, zredukowana do podziału ścian na cokół, wyodrębniony kolorystyką i fakturą, i oddzieleniu dwóch środkowych kondygnacji od ostatniej wydatnym gzymsem. Gimnazjum rozpoczęło użytkowanie nowego budynku w 1933 roku, a oprócz sal szkolnych znalazło się w nim kilka mieszkań służbowych dla dyrektora i nauczycieli.

Budynek szkół powszechnych nr 7, 11 i 22 (obecnie przedszkole nr 14) przy ul. Bronowickiej 3 również można sklasyfikować pomiędzy architekturą nawiązującą do form historycznych, a modernizmem, choć jego forma bliższa jest temu drugiemu. Projekt szkoły z 1930 roku, na zrębie parterowego budynku dawnej rzeźni miejskiej z końca XIX wieku, został zrealizowany do 1933 roku. Prace prowadziło Biuro Budowlano-Handlowe „Architekt” Franciszka Papiewskiego, które w owym czasie niemal zmonopolizowało wykonawstwo prac budowlanych na terenie Lublina ${ }^{11}$. Projekt przewidywał realizację trzykondygnacyjnego symetrycznego budynku, założonego na rzucie litery $\mathrm{H}$, z prostokątnym korpusem głównym i prostopadłymi bocznymi skrzydłami, wystającymi przed lica obu dłuższych elewacji (il. 5).

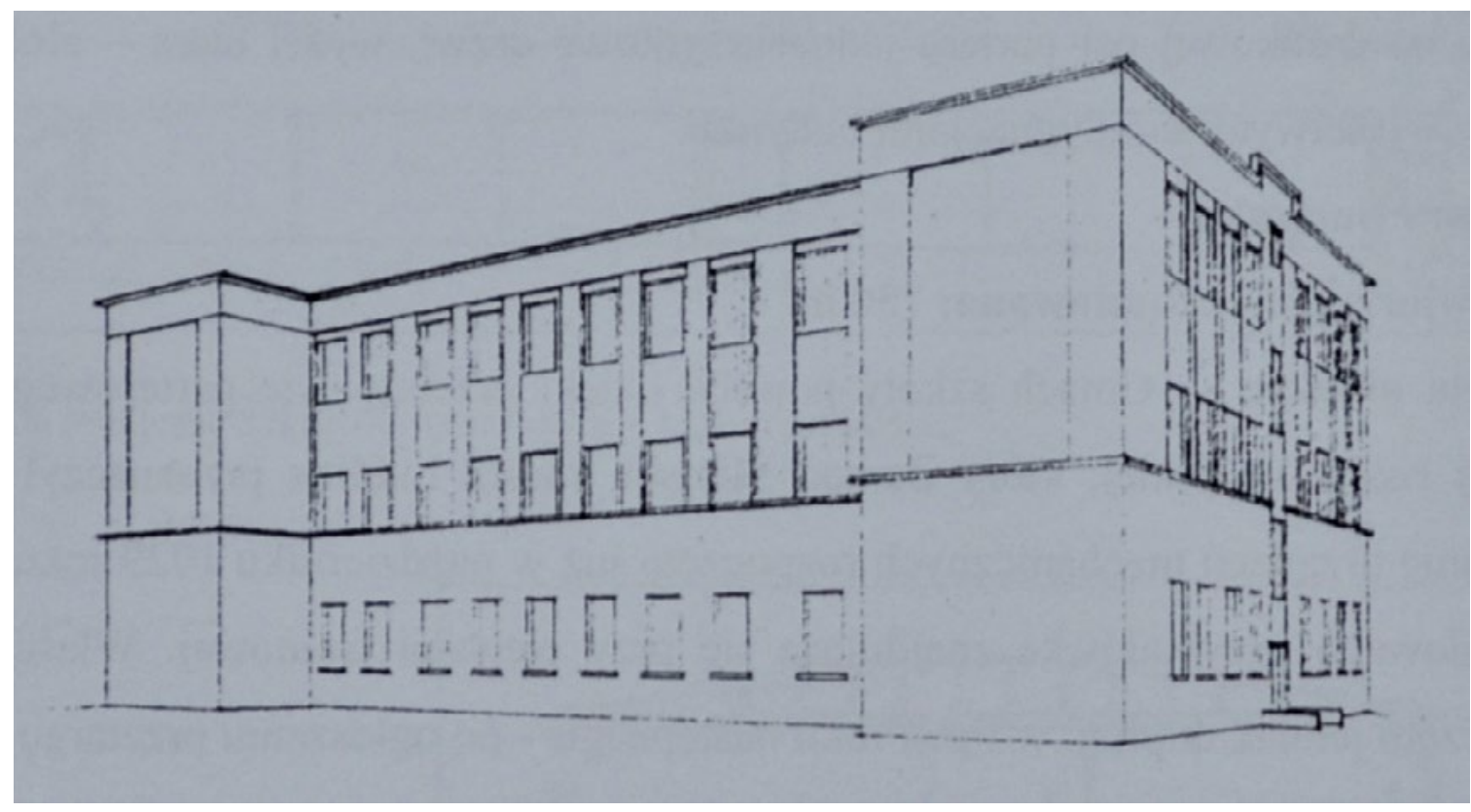

Ryc. 5. Szkoła powszechna $\mathrm{nr}$ 7, 11 i 22, proj. 1930, aksonometria, za: APL IB, syg. 205, kopia projektu za zgodą Archiwum Państwowego w Lublinie

Echa historyzującej w formie artykulacji ścian przywołuje swoisty gładki cokół, jaki tworzy dolna kondygnacja dla dwóch wyższych, zaakcentowany gzymsem. Podziały osi środkowego korpusu zostały zredukowane do wspartych na cokole pasów lizen w wielkim porządku, powtórzonych na flankach ryzalitów, na którym oparto schematyczne "belkowanie". Jednak ogólny wyraz bryły, nakrytej czterospadowym dachem, jest już modernistyczny. Ślepe, niemal gładkie ryzality działają swoją masą i optycznie rozczłonkowują gmach na pozornie

10 APL IB, Akta nieruchomości położonej przy Al. Racławickich 20 w Lublinie, sygn. 4260; APL UWL WKB, Remont budynku Państwowego Gimnazjum im. S. Staszica w Lublinie, sygn. 2956.

11 APL IB, Akta nieruchomości położonej przy ul. Bronowickiej 3 w Lublinie, sygn. 205; APL AmL, Szkoty i baraki 1930-1934 (budowa szkoty powszechnej na Bronowicach), sygn. 1830; APL AmL, Sprawy przebudowy rzeźni na Bronowicach na szkołę powszechna 1929-1939, sygn. 3721. 
niezależne bryły. Rozplanowanie wnętrza zakładało realizację sześciu sal lekcyjnych na każdej z trzech kondygnacji oraz dwóch obszernych korytarzy komunikujących sale w korpusie głównym z pomieszczeniami bocznych skrzydeł (także sale, umywalnie, pokoje nauczycielskie i dyrektorskie) i znajdującymi się w ich obrębie klatkami schodowymi. Korytarze - tzw. "rekreacje" - pełniły także funkcje przestrzeni do wypoczynku uczniów podczas przerw i zajęć wychowania fizycznego zimową porą, podobnie jak w wielu innych, "ekonomicznych" projektach szkół, w których rezygnowano z odrębnych sal gimnastycznych.

\section{Modernizm}

W pełni modernistyczną formę prezentują budynki szkół powstałe w drugiej połowie lat 30. XX wieku. W wyniku zamkniętego konkursu na projekt szkół powszechnych nr 1 i 14, ogłoszonego na przełomie 1934 i 1935 roku, spośród propozycji czterech, zaproszonych do udziału w nim architektów, główną nagrodę otrzymał Tadeusz Witkowski ${ }^{12}$. Okazały gmach stanął na wyasygnowanej na ten cel przez miasto 1,5-hektarowej parceli przy ul. Bychawskiej (ob. Kunickiego) w dzielnicy Dziesiąta. Niewykończony w pełni budynek oddano do użytku w 1936 roku, chociaż budowa trwała etapami do pocz. lat 50. XX wieku. Rzut obiektu wraz z parterowym budynkiem sali gimnastycznej jest zbliżony do litery $T$, z silnie wydłużonym symetrycznym korpusem z ryzalitem na osi głównej i w narożach tylnej elewacji. O wyrazie architektonicznym gmachu decyduje zrównoważenie poziomych ciągów okien oraz wertykalnego układu ryzalitu na osi, nieznacznie wyższego od pozostałej części budynku, i pionowych dekoracji z bordowej klinkierowej cegły, wypełniających przestrzeń między oknami. Efekty światłocieniowe centralnego ryzalitu podkreślają niemal pełnoplastyczne lizeny wystające ponad gzyms. Niestety, wyjątkową dbałość o jakość i kolorystykę materiałów zastosowanych do wykończenia elewacji frontowej - płyty jasnego piaskowca ułożone w poziomych pasach między oknami, czy barwiony na kolor zgaszonego różu chropowaty tynk, zniweczyła nieudana termomodernizacja budynku przeprowadzona zaledwie kilka lat temu, w wyniku której nastąpiła zmiana kolorystyki, faktury i częściowa utrata oryginalnych okładzin. Na „otarcie łez" warto wspomnieć, iż projektowany pierwotnie przez Witkowskiego taras na dachu budowli doczekał się w końcu realizacji, będąc ciekawym przykładem współczesnego wdrożenia jednego z punktów idei architektury nowoczesnej Le Corbusiera.

Bliźniacze szkoły powszechne nr 8 i 13 (obecnie siedziba V LO im. Marii Skłodowskiej-Curie, ul. Lipowa 7), otrzymały siedzibę zaprojektowaną przez architekta Kazimierza Barszczewskiego w 1938 roku, ukończoną wstępnie w czasie wojny, ostatecznie pod koniec lat $40 .{ }^{13}$, chociaż ich historia sięga 1922 i 1925 roku, kiedy wstępne szkice o znamionach architektury dworkowej z ramienia Wydziału Budownictwa lubelskiego Magistratu wykonał Ignacy Kędzierski, o których wspomniano już wcześniej. Ostatecznie, jak już wiemy, nie zostały zatwierdzone i do tematu powrócono dopiero z końcem lat 30., organizując konkurs zamknięty z udziałem pięciu lubelskich architektów ${ }^{14}$. Mimo że żadna z przedstawionych propozycji nie wzbudziła nadmiernego entuzjazmu, sąd konkursowy przekazał do realizacji projekt Barszczewskiego, z zastrzeżeniem wprowadzenia stosownych zmian w zakresie dyspozycji wnętrz i oświetlenia sal lekcyjnych, zgodnie z wytycznymi Ministerstwa Wyznań Religijnych i Oświecenia Publicznego. Główne prace budowlane powierzono firmie W. Szczepańskiego. Gmach usytuowany u zbiegu ulic Lipowej i Skłodowskiej został założony na nieregularnym wydłużonym planie. Architekt dość swobodnie, uskokowo zestawił pięć prostopadłościennych, zróżnicowanych na przemian wysokościami, brył. Naprzemienny rytm podtrzymuje artykulacja elewacji poszczególnych członów budowli: nieco niższe, wysunięte ku przodowi wypełniają pasy okien w pięciu osiach, których horyzontalizm podkreślają pozbawione jakiejkolwiek dekoracji, choćby w postaci płycin, pasy gładkiego muru pomiędzy kolejnymi kondygnacjami. W kontraście z nimi pozostają dwa wyższe, ale za to cofnięte człony korpusu, których frontowe,

12 Do konkursu oprócz Witkowskiego (I nagroda - 600 zł) zaproszono Bohdana Kelles-Krauzego (II nagroda), Stanisława Łukasiewicza (III nagroda) i Jerzego Chylewskiego (IV nagroda). Pierwszy projekt wykonany w 1934 roku przez Józefa Rogowskiego nie został zatwierdzony ze względu na brak mieszkań dla pracowników i sali gimnastycznej, chociaż z przyjętego projektu ostatecznie nie zrealizowano skrzydła mieszkalnego od południa. Zob.: [Danczowska 2009: 145-146].

13 APL IB, sygn. 2507, 2508; APL AmL, Budowa szkoty przy ul. Lipowej 1922-1933, sygn. 1831; APL AmL, Budowa szkoty przy ul. Lipowej 1938, sygn. 1832; APL AmL, Sprawy budowy nowych szkót 1935, sygn. 3724; APL AmL, Sprawy budowy nowych szkót 1938, sygn. 3727.

14 Byli to Leon Banaszewski, Kazimierz Barszczewski, Edward Kranz, Stanisław Łukasiewicz i Tadeusz Witkowski. Oprócz Barszczewskiego wszyscy w/w architekci mogli pochwalić się projektami placówek szkolnych lub kulturalno-oświatowych w swoim dorobku, chociaż ostatecznie Witkowski projektu nie przedstawił. 
sześcioosiowe elewacje niemal szczelnie wypełniają pionowe wielopolowe okna, jednoznacznie wskazując pracę żelbetowego szkieletu, dźwigającego całą konstrukcję. Wertykalizm podkreślają także pasy lizen, które wraz z wydzielonym cokołem mogą sugerować odległe i już nieczytelne nawiązania do klasycyzmu akademickiego.

Tadeusz Witkowski, oprócz projektu szkół bliźniaczych na Dziesiątej, wykonał jeszcze jeden interesujący, choć niezrealizowany projekt - powstał w 1939 roku - budynku szkolnego przeznaczonego dla prywatnego Gimnazjum Elektrycznego i Mechanicznego na parceli przy Al. Długosza. Miał on pomieścić gimnazja wywodzące się z prywatnej szkoły rzemieślniczej Stanisława Śliwińskiego i Stanisława Syroczyńskiego, powstałe w drugiej poł. lat 30. XX wieku [Arciszewski, Jakóbczyk: 1994] ${ }^{15}$. Wybuch II wojny światowej zniweczył rozpoczęte plany, a do projektu Witkowskiego po wojnie już nie powrócono. Architekt zaproponował bryłę w pełni nowoczesną w formie i konstrukcji, która równie aktualnie mogłaby wyglądać na tle przykładów powojennego modernizmu (il. 6).

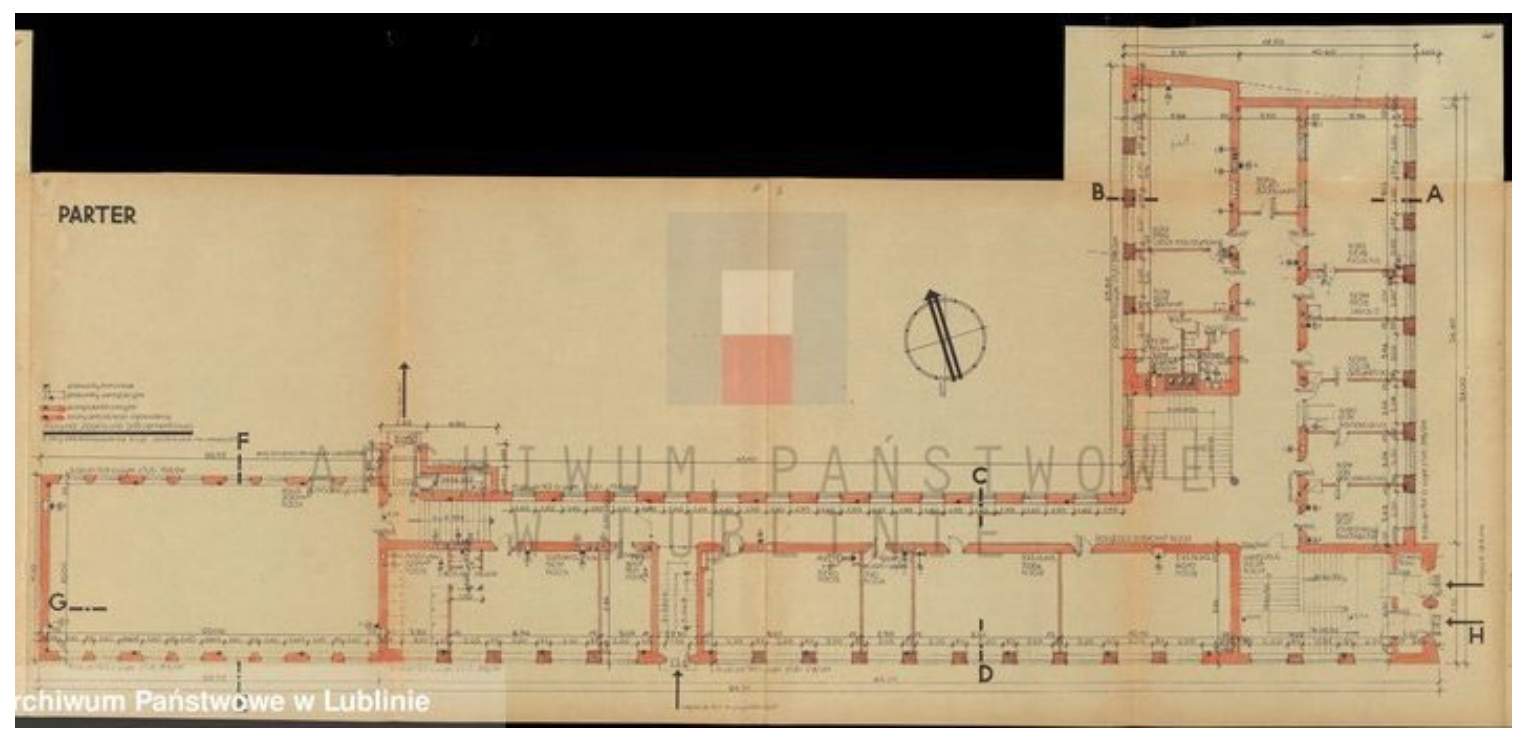

Ryc. 6. Niezrealizowany projekt Gimnazjum Elektrycznego przy Al. Długosza, proj. T. Witkowski 1939, rzut parteru, za: APL UWL-V-WKB, sygn. 1491, , kopia projektu za zgodą Archiwum Państwowego w Lublinie

Główną cechą projektowanej budowli o płaskim dachu jest jej asymetria, począwszy od rzutu w kształcie litery L, poprzez zróżnicowane wysokości poszczególnych partii i sposobu opracowania elewacji, po ich artykulację (il. 7). Architekt, podobnie, jak w swoim projekcie szkół bliźniaczych nr 1 i 14, zaproponował tu wypełnienie przestrzeni pionowych pomiędzy oknami cegłą klinkierową, równoważącą ich horyzontalny rytm, nadany również przez potrójne poziome pasy gładkiego muru pomiędzy poszczególnymi kondygnacjami. 


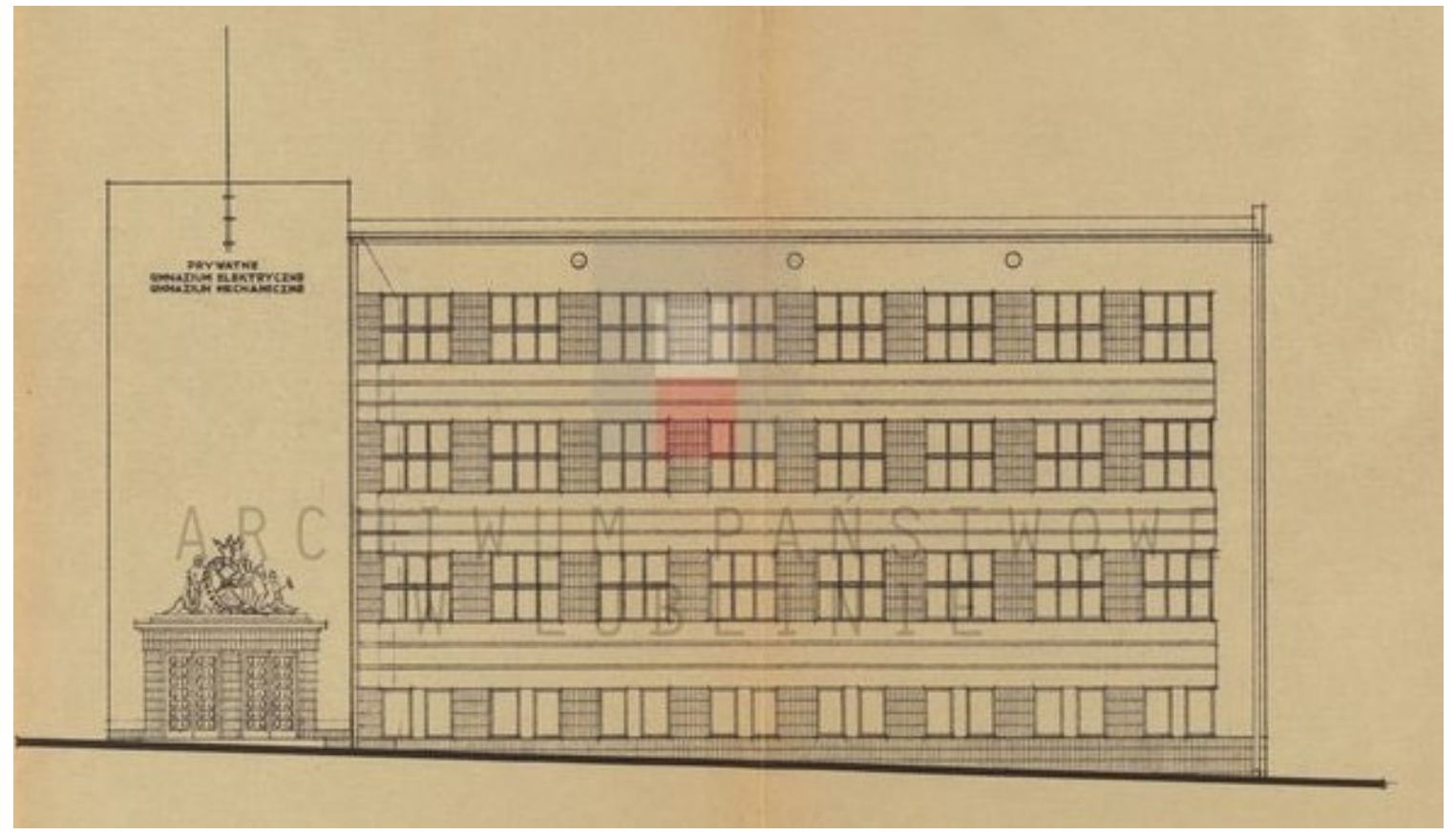

Ryc. 7. Niezrealizowany projekt Gimnazjum Elektrycznego przy Al. Długosza, proj. T. Witkowski 1939, widok od Al. Długosza, za: APL UWL-V-WKB, sygn. 1491, kopia projektu za zgodą Archiwum Państwowego w Lublinie

Asymetria w kształtowaniu bryły charakteryzuje także Średnią Szkołę Budownictwa przy Al. Długosza (ob. Państwowe Szkoły Budownictwa i Geodezji), która została zrealizowana w latach 1931-1936, według projektu konkursowego architekta Stanisława Łukasiewicza, od 1931 roku także jej dyrektora [Łukasiewicz 1931: 25$28]^{16}$ i już wkrótce autora projektu Lubelskiego Domu Pracy Kulturalnej. Z przewidywanych 4 etapów budowy przed wybuchem wojny zdołano zakończyć tylko pierwszy, z fragmentem skrzydła północno-zachodniego (il. 8). Nowe skrzydła zaprojektowane m.in. przez Czesława Dorię-Dernałowicza zrealizowano etapami w latach 50. i 60. XX wieku, w nawiązaniu do pierwotnej koncepcji Łukasiewicza. W oryginalnym projekcie całe założenie, na rzucie zbliżonym do litery $C$, zostało pomyślane jako swobodne zestawienie kilku brył. Narożnik budynku tworzy tu samodzielną strukturę, z klatką schodową wypełnioną łączonymi w pionie okienkami i usytuowanym asymetrycznie wejściem. 


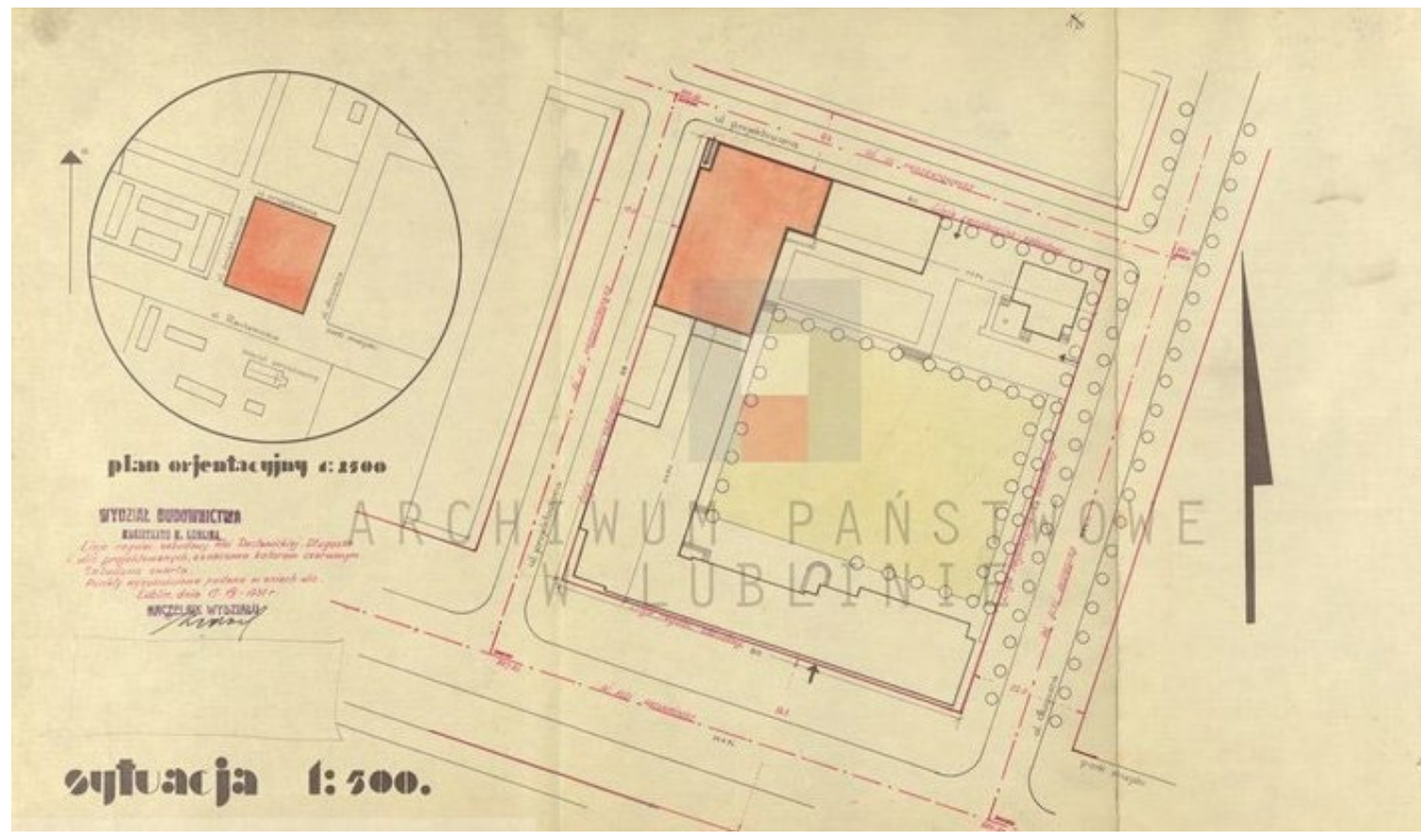

Ryc. 8. Szkoła Budownictwa przy Al. Długosza, proj. S. Łukasiewicz 1931, sytuacja, za: APL UWL-V-WKB, sygn. 1489, kopia projektu za zgodą Archiwum Państwowego w Lublinie

Podobna kompozycja przestrzenna charakteryzuje projekt szkół powszechnych 4 i 20 Leona Banaszewskiego z 1937 roku, w którym wyższy od reszty korpusu narożnik został dodatkowo wyodrębniony kolorystycznie ciemną okładziną. Obiekt, obecnie nieistniejący, niegdyś na rogu ulic Lubartowskiej i Obywatelskiej, łączył drewnianą konstrukcję słupowo-kleszczową ścian z żelbetowym szkieletem klatek schodowych.

Na końcu warto wspomnieć - choć już nieco na marginesie rozważań stylowych i geograficznych - dwa lubelskie obiekty, które w okresie międzywojennym znajdowały się poza granicami miasta i były projektowane jako wiejskie szkoły siedmioklasowe. Są to nadal istniejące budynki przy ul. Romantycznej 11 (dawniej szkoła powszechna w Rurach Jezuickich) i przy ul. Zdrowej 1 (wówczas szkoła powszechna w Głusku), projektu Bohdana Kelles-Krauzego. Szkoła w Głusku (obecnie Przedszkole miejskie nr 83) - projekt z 1926 roku - posiada dość prostą bryłę z elementami osadzającymi budynek w kręgu wpływów form historycznych, takimi jak stosunkowo stromy dach i ryzalit na osi zwieńczony attyką z kamienną kulą na szczycie [por. Błotnicka-Mazur 2011: 82-85]. Co ciekawe, po drobnej korekcie, ten sam projekt o zupełnie odmiennym wyrazie architektonicznym, został zrealizowany dla potrzeb szkoły powszechnej w Dzierzkowicach w drugiej połowie lat 30. XX wieku (ob. Zespół Placówek Oświatowych w Terpentynie). Dawną szkołę na Rurach, chociaż chronologicznie nieco późniejszą, bo zaprojektowaną w 1929 roku, formalnie łączy z tradycją podobna attyka - tu o uskokowym kształcie, zdobiąca płytki, asymetrycznie usytuowany ryzalit. Budynek nadal pełni swoją funkcję, stanowiąc wydzieloną enklawę dydaktyczną dla klas I-III szkoły podstawowej $\mathrm{nr} 28$.

\section{Podsumowanie}

Zewnętrzna szata obiektów szkolnych, zaprojektowanych i/lub zrealizowanych w okresie dwudziestolecia międzywojennego w Lublinie jest odbiciem tendencji swojego czasu i aktualnych wówczas trendów architektonicznych. W większości były to projekty wykonane przez lubelskich architektów, doświadczonych w zakresie budownictwa o charakterze publicznym, takich jak Ignacy Kędzierski i Jerzy Siennicki, lub przez utalentowanych reprezentantów młodszego pokolenia, np. Stanisława Łukasiewicza i Tadeusza Witkowskiego. I tak w latach 20. XX wieku dominuje architektura o charakterze narodowym, nawiązująca do modnego w tym czasie stylu "dworkowego". Na przełomie lat 20. i 30. cechą wspólną obiektów oscylujących pomiędzy tradycją a nowoczesną formą jest 
ich symetryczność i osiowość - w większości przypadków, tradycyjne podziały kompozycyjne elewacji na cokół, część środkową i wieńczącą oraz pojawiające się tu i ówdzie, zredukowane już wprawdzie, detale architektoniczne, takie jak: boniowanie, pilastry i gzymsy. W latach 30., a szczególnie w drugiej połowie, obiekty szkolne buduje się w duchu funkcjonalizmu, nowocześnie pod względem zarówno konstrukcji, jak i formy. Swobodne zestawianie brył w asymetryczne kompozycje przestrzenne było domeną zwłaszcza młodych projektantów, bardziej otwartych na postulaty Le Corbusiera. Pomimo pośpiechu i zrozumiałych problemów finansowych, z jakimi musiały borykać się władze miejskie na każdym etapie realizacji projektów, pojawiło się w Lublinie kilka obiektów funkcjonalnych i reprezentacyjnych zarazem, o czym najlepiej świadczy fakt, iż w większości nadal z powodzeniem pełnią swoją pierwotną funkcję.

\section{Piśmiennictwo}

[1] Arciszewski W., Jakóbczyk J. (red.): 1994, Od Szkoły Rzemieślniczej im. Stanisława Syroczyńskiego do Zespołu Szkół Energetycznych w Lublinie 1914-1994, Lublin.

[2] Błotnicka-Mazur E.: 2011, Projekty architektoniczne Bohdana Kelles-Krauzego w zasobie Archiwum Państwowego w Lublinie $i$ innych zbiorach archiwalnych, Lublin.

[3] Danczowska H.: 2009, Architekt Tadeusz Witkowski (1904-1986), kalendarium życia i twórczości, Lublin.

[4] Dobrowolski T. (red.): 1928, Monografia m. Lublina za czas od 1917 do 1927 roku, Lublin.

[5] Holewiński J.: 1921, Budynek szkolny, Warszawa.

[6] Holewiński J.: 1908, O budowie i urządzeniu szkót. Podręcznik praktyczny, Warszawa.

[7] Janeczek A.: 2004, Architektura użyteczności publicznej 1918-1939 w Lublinie, praca magisterska napisana pod kierunkiem dr hab. Lechosława Lameńskiego, prof. nadzw. KUL, Lublin, mps w Katedrze Historii Sztuki Nowoczesnej i Współczesnej KUL.

[8] Ł.[ukasiewicz] S.: 1931: Szkoła Budownictwa w Lublinie, „Technik Lubelski”, nr 10-11, 25-28.

[9] Przesmycka E., Miłkowska E.: 2011, Wzorcowe szkoły wiejskie jedno- $i$ dwuklasowe z okresu międzywojennego w Polsce, "Teka Kom. Arch., Urb. Stud. Krajobr. PAN, Oddz. Lublin", t. VII, 168-176.

[10] Przesmycka E., Rzączyńska E.: 2008, Architektura szkół okresu międzywojennego Elżbiety Przesmyckiej i Ewy Rzączyńskiej, "Teka Kom. Arch., Urb. Stud. Krajobr. PAN, Oddz. Lublin", t. IVb, 234-248.

[11] Pszczółkowski M.: 2014, Architektura użyteczności publicznej II Rzeczypospolitej 1918-1939. Forma i styl, Łódź.

[12] Pszczółkowski M.: 2015, Architektura użyteczności publicznej II Rzeczypospolitej 1918-1939. Funkcja, Łódź.

\section{Between Tradition and Modernism. The Architecture of School Buildings in the Interwar Lublin}

Abstract: The paper presents architectural plans of selected school buildings, designed during the interwar period in Lublin. Their architectural style is characterized by changes typical for tendencies present in Polish architecture at the moment: from traditionalism, popular in the 1st half of the 1920s, through gradual simplification of the detail and the shape of the building in the 2 nd half of the 1920 s, up to mature modernism of the 2 nd half of the 1930 s.

Key words: school buildings architecture, interwar period, traditionalism, modernism 